\title{
Bisnis Keluarga di Bandung Bagaimana Mereka Bertahan-Berlanjut?
}

\author{
Budiana Gomulia \\ Fakultas Ekonomi Universitas Katolik Parahyangan \\ J1. Ciumbuleuit No. 94, Bandung \\ E-Mail: budiana@unpar.ac.id
}

\begin{abstract}
The Family business in Indonesia having capability to survive-sustain. Begin when the founder started his business, he fought remarkable that business can thrive. In order the business continues to grow and "built to last" there are many aspects and factors that must be considered, including regeneration by successors and professionalization of management. Three Dimention Development Model (Davis et al, 1997) will describe the situation of family business in Bandung consiting of The development of business, The development of family and The development of ownership. This research was conducted in three semesters, in 2011 and 2012. Using a sample of 45 companies from a variety of ages and types of business This research is descriptive -multikasus. The process of interview, observation and discussions with respondents in companies carried out by the students as a class assignment. Family Business Management class is organized by the Department of Management in Unpar.It seems the family business in Bandung can survive into old age, can reach 50 years and over. Succession from the first generation to next generation already happened or is happening. The sustainability of the business due to family commitments and a strong family beliefs. Most family business is in the mature stage, although the management and ownership is still controlled by family members.
\end{abstract}

Keywords: family business, three dimention development model.

\begin{abstract}
ABSTRAK
Bisnis Keluarga di Indonesia memiliki kemampuan bertahan-berlanjut. Diawali ketika seseorang "founder" memulai bisnisnya, kemudian dengan perjuangannya bisnis itu berkembang. Agar bisnis dapat terus tumbuh dan berlanjut "Built to Last" terdapat banyak aspek dan faktor yang harus diperhatikan, di antaranya regenerasi oleh penerusnya dan profesionalisasi manajemennya. Memotret bisnis keluarga di Bandung dalam pandangan Model Tiga Dimensi Perkembangan (Davis et al, 1997), meliputi: perkembangan dimensi bisnis, perkembangan dimensi keluarga, dan perkembangan dimensi kepemilikan. Penelitian dilakukan dalam tiga semester pada tahun 2011 dan 2012. Memanfaatkan 45 sampel perusahaan dari beragam usia bisnis dan jenis usaha. Penelitian ini merupakan penelitian deskriptif dengan multikasus. Proses wawancara, observasi dan diskusi dengan responden pada setiap perusahaan dengan menugaskan mahasiswa di kelas Manajemen Bisnis Keluarga yang diselenggarakan oleh Jurusan Manajemen Unpar. "Tampaknya" bisnis keluarga di Bandung mampu bertahan dan berlanjut sampai usia panjang, bahkan ada yang telah mencapai lebih dari 50 tahun, dimana suksesi dari generasi pertama ke generasi penerus sudah atau sedang terjadi. Faktor yang menyebabkan adanya keberlanjutan adalah komitmen keluarga dan kepercayaan pada keluarga yang masih sangat kuat. Bisnis keluarga yang diteliti umumnya berada pada tahap dewasa dengan manajemen dan kepemilikannya masih dikuasai keluarga.
\end{abstract}

Kata Kunci: bisnis keluarga, model perkembangan tiga dimensi. 


\section{PENDAHULUAN}

Jumlah bisnis keluarga di Indonesia diperkirakan tidak kurang dari 95\% dari seluruh bisnis yang ada. Sementara berdasarkan berbagai penelitian, telah diketahui bahwa di berbagai negara di dunia, 50\%-80\% bisnis merupakan bisnis keluarga dengan kontribusi yang besar dalam perekonomian. Kajian bisnis keluarga sudah mendapat perhatian para peneliti di berbagai Perguruan Tinggi di dunia dan menjadi sangat berkembang dalam dua dekade terakhir ini.

Bisnis keluarga yang didirikan di Indonesia memiliki kemampuan untuk bertahan dan berkembang. Hasil penelitian David dan Lenny (2007) menunjukkan bahwa 3\% bisnis keluarga yang didirikan antara tahun 1932-1943 masih ada sampai saat ini, sedangkan yang didirikan pada tahun 19441955 masih bertahan 2\% saja. Selanjutnya perusahaan keluarga yang berdiri setelah kondisi politik dan ekonomi Indonesia menjadi semakin stabil (periode 1968-1979, 1980-1991, 1992-2003) ternyata yang dapat tetap bertahan lebih besar, yaitu antara 10\% sampai $37 \%$. Statistik itu rasanya tidak mengejutkan, karena sepertinya menyetujui pernyataan ini yang menjadi mitos "generasi pertama membangun bisnis, generasi kedua menikmatinya, lalu generasi ketiga menghancurkannya".

Banyak sumber pustaka memaparkan siapa dan apa bisnis keluarga tersebut. Definisi yang cukup sederhana adalah yang dikatakan Lizz (1995) "The essence of a family firm, that is the intention of the family to retain control of the business past to the current generation" dan definisi dari Winter et al. (1998), "Family business as a business that is owned and managed by one or more family member".

Penelitian Keberlanjutan Bisnis Keluarga di Bandung dilakukan untuk melihat aspek-aspek penting dalam perkembangan bisnis keluarga dengan menggunakan "Three Dimention model" dari Davis et al. (1997).

\section{Keberlanjutan dan Perkembangan Bisnis Keluarga}

Setiap bisnis yang mulai dibangun tentunya dimaksudkan untuk dapat terus berkembang. Dianalogikan dengan kelahiran setiap manusia, secara alamiah mereka akan membesar dan menjadi orang dewasa, kemudian menjadi tua dan seterusnya. Kenyataannya dapat dilihat bahwa perkembangan setiap manusia, berbeda satu dengan yang lain; sangat bersifat individual. Gambaran yang sama akan terjadi juga pada setiap bisnis.

Davis et al. (1997), memberikan dua cara pandang terhadap perkembangan bisnis. Pertama sebagai reaksi terhadap lingkungan luar, sehingga pola perkembangan internal terjadi sebagai sifat individu yang unik dan aneh. Tahap tahap, waktu, dan karakteristiknya tidak bisa digeneralisasi. Sedangkan pandangan kedua, akibat reaksi terhadap lingkungan eksternal, perkembangan internal akan berubah sesuai tahapan kedewasaan yang diperkirakan.

Pendekatan siklus hidup bisnis mempelajari pertumbuhan-perkembangan bisnis sebagai tahap berurutan tertentu (ada pola umum yang digunakan) yang akan dilalui sepanjang waktu hidup bisnis. Didukung oleh Kimberly dan Miles (1980) "... the theoritical notion of the life cycle is dictinctly deterministic, as organizations inexorably pass from one stage to the next over time"

Perkembangan yang terjadi akan mengandung nilai pertumbuhan (dalam berbagai dimensi dan ukuran yang dapat digunakan) dan nilai kompleksitas (semakin dewasa akan semakin rumit variabel dan hubungannya). Greiner (1972) membahas model perkembangan organisasi terkini. Terdapat lima dimensi utama yang membangun model pertumbuhan dan perkembangan organisasi, yaitu: 1) Umur dari organisasi, 2) Ukuran dari organisasi, 3) Tahap perubahan evolusi, 4) Tahap perubahan revolusi, dan 5) Tingkat pertumbuhan dari industri. Sedangkan Quinn (1983), mengatakan bahwa perkembangan akan dipengaruhi oleh faktor lingkungan eksternal dan internalnya. Lingkungan eksternal yang akan dihadapi berbeda bila bisnis berada dalam industri yang berbeda. Lingkungan internal berbeda bila umur, ukuran, struktur, dan budaya berbeda.

Perkembangan bisnis secara garis besarnya dapat diperkirakan ada tahapan-tahapannya, tetapi perkembangan detail setiap bisnis memiliki keunikan satu dengan yang lain.

\section{Model Perkembangan Tiga Dimensi}

Buku Generation to Generation karangan Davis et al. (1997) membahas Model Perkembangan Tiga Dimensi dengan paparan yang lengkap dan sangat menarik. Model ini terbentuk setelah para peneliti melakukan penelitian yang panjang terhadap beberapa bisnis keluarga terkenal di USA seperti Caterpillar, Wall Mart, Cargill, McGraw-Hill, dan lain-lain. 
Model perkembangan ini adalah tiga lingkaran sistem bisnis keluarga: lingkaran bisnis-manajemen, lingkaran kepemilikan, dan lingkaran keluarga. Memasukkan unsur perubahan perkembangan sepanjang waktu dalam tiga lingkaran bisnis keluarga tersebut. Digambarkan dalam Gambar 1. dengan tiga dimensi-aksis perkembangan (siklus hidup) yang masing-masing terpisah (sendiri-sendiri).

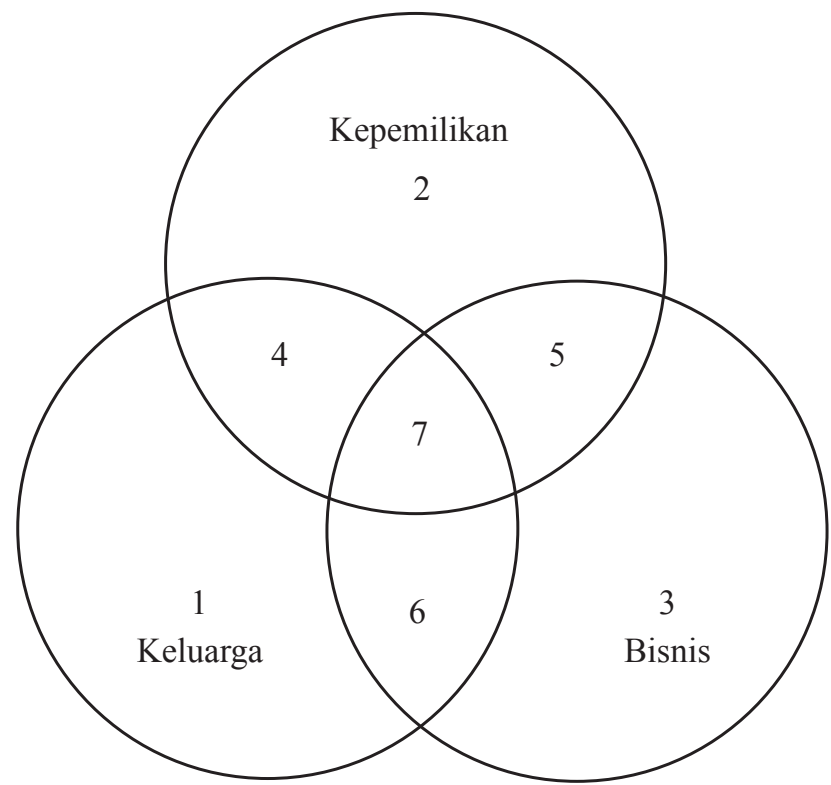

Sumber: Tagiuri dan Davis (1996:199-208) dalam Louise (2007)

Gambar 1. Lingkaran dalam Perusahaan Keluarga

Dengan menggabungkan ketiga siklus itu, maka posisi perkembangan setiap bisnis keluarga pada suatu saat akan berada pada sebuah titik di posisi aksis perkembangan kepemilikan, sebuah titik di aksis perkembangan bisnis dan sebuah titik di aksis perkembangan keluarga. Dengan berjalannya waktu posisi aksis perkembangan bisnis keluarga (Tiga Dimensi) dapat berubah.
Untuk menentukan tahap pertumbuhan bisnis pada saat tertentu bukan persoalan mudah. Hal itu memerlukan penilaian pihak berwenang, dan mungkin saja harus merupakan hasil kesepakatan bersama, seperti yang dikatakan oleh Miller dan Friesen (1984) "...The life cycle is more collective interpretation of the organization's environment based on an assesment by top management". Sebagian besar perkembangan bisnis, tahapan-tahapannya tidak tampak berurutan jelas seperti perkembangan biologis manusia.

Model Tiga Dimensi Perkembangan, memiliki perangkat yang lebih lengkap untuk memotret perkembangan sebuah bisnis keluarga, sehingga dapat memastikan bahwa tahapan-tahapan itu dapat ditemukan dan ditentukan dengan tingkat kepastian yang memadai. Untuk keperluan penilaian, model ini membutuhkan suatu teknik pengukuran dan kesepakatan yang melibatkan pelaku yang memiliki spesifikasi keahlian tertentu.

\section{Perkembangan Kepemilikan, Perkembangan Bisnis-Manajemen, dan Perkembangan Keluarga}

Pada masing-masing dimensi perkembangan, memiliki beberapa tahap atau posisi (siklus) dengan pencirinya. Pada perkembangan kepemilikan yang biasa terjadi dalam bisnis keluarga, terdapat tiga tahap yaitu: Pengendalian pemilik, Rekanan sekandung, dan Gabungan keluarga besar. Untuk mengenali setiap tahap yang sedang terjadi dapat diketahui dari cirinya dapat dilihat pada Tabel 1. Pada perkembangan Bisnis-Manajemen terdapat 3 tahap: (1) Memulai Usaha, (2) Ekspansi dan formal, dan (3) Dewasa. Masing-masing memiliki pencirinya, dapat dilihat pad Tabel 2. Pada perkembangan Keluarga ada 4 tahap: (1) Bisnis keluarga muda, (2) Generasi kedua memasuki bisnis, (3) Kerja bersama, dan (4) Menyerahkan tongkat. Untuk melihat ciri-ciri yang dapat membedakan satu tahap dengan yang lainnya, dapat dilihat Tabel 3 .

Tabel 1. Ciri-Ciri Perkembangan Kepemilikan

\begin{tabular}{lll}
\hline \multicolumn{1}{c}{ Pengendalian Pemilik } & \multicolumn{1}{c}{ Rekanan Sekandung } & \multicolumn{1}{c}{ Gabungan Keluarga Besar } \\
\hline $\begin{array}{l}\text { Kepemilikan ada di bawah pengendalian } \\
\text { satu orang atau pasangan suami istri. }\end{array}$ & $\begin{array}{l}\text { Kepemilikan utama oleh dua atau lebih } \\
\text { saudara sekandung. }\end{array}$ & Dimiliki oleh banyak keponakan. \\
$\begin{array}{l}\text { Bila terdapat pemilik lain, hanya sebagai } \\
\text { pemilik pasif. }\end{array}$ & $\begin{array}{l}\text { Pengendalian efektif ditangan satu } \\
\text { generasi sekandung. }\end{array}$ & $\begin{array}{l}\text { Campuran antara pemilik yang bekerja } \\
\text { (mengontrol) dan pemilik yang tidak ikut } \\
\text { bekerja (mengontrol). }\end{array}$ \\
\hline
\end{tabular}


Tabel 2. Ciri-Ciri Perkembangan Bisnis-Manajemen

\begin{tabular}{lll}
\hline \multicolumn{1}{c}{ Memulai Usaha } & \multicolumn{1}{c}{ Ekspansi dan Formal } & \multicolumn{1}{c}{ Dewasa } \\
\hline $\begin{array}{l}\text { Struktur organisasi informal, dengan } \\
\text { pemilik dan manajer sebagai pusatnya. }\end{array}$ & $\begin{array}{l}\text { Meningkatnya kebutuhan } \\
\text { membangun struktur-sistem. }\end{array}$ & Struktur organisasi mendukung stabilitas. \\
$\begin{array}{l}\text { Memproduksi hanya satu produk atau } \\
\text { unit bisnis. }\end{array}$ & $\begin{array}{l}\text { Membangun dan memproduksi } \\
\text { beragam produk dan lini bisnis. }\end{array}$ & $\begin{array}{l}\text { Basis pelanggan yang sudah stabil - menurun } \\
\text { dengan pertumbuhan biasa. } \\
\text { Struktur divisional digunakan pada tim } \\
\text { manajemen senior. }\end{array}$ \\
& & Rutinitas organisasi yang sudah berjalan baik. \\
\hline
\end{tabular}

Tabel 3. Ciri-Ciri Perkembangan Keluarga

\begin{tabular}{|c|c|c|c|}
\hline Bisnis Keluarga Muda & Generasi Kedua Memasuki Bisnis & Kerja Bersama & Menyerahkan Tongkat \\
\hline $\begin{array}{l}\text { Pendiri berumur di bawah } 40 \\
\text { tahun. Anak-anaknya berumur } \\
\text { di bawah } 18 \text { tahun. }\end{array}$ & $\begin{array}{l}\text { Generasi terdahulu-tua berumur } \\
\text { antara } 35 \text { dan } 45 \text { tahun. Generasi } \\
\text { berikut-muda berumur belasan } \\
\text { tahun dan dua puluhan. }\end{array}$ & $\begin{array}{l}\text { Generasi tua yang berumur } 50 \\
\text { dan } 60 \text { tahun. Generasi muda } \\
\text { antara } 20 \text { dan } 40 \text { tahun. }\end{array}$ & $\begin{array}{l}\text { Generasi tua sudah } \\
\text { berumur } 60 \text { tahun } \\
\text { ke atas. }\end{array}$ \\
\hline
\end{tabular}

\section{METODE}

Objek penelitian ini adalah pengusaha keluarga berskala UKM, yang berada di Bandung dan sekitarnya. Perusahaan yang sudah berdiri minimal lima tahun. Jenis usahatidak dibatasi. Pemilihan sasaran perusahaan yang diteliti secara "snowball sample". Responden dari penelitian ini adalah orang-orang kunci di perusahaanperusahaan tersebut: pemilik, direktur, staf utama, dan keluarga dekat pemilik.

Penelitian ini merupakan penelitian deskriptif. Dengan menggunakan desain penelitian kualitatif: tidak dimaksudkan untuk menggeneralisasi dan lebih mencari makna (subjektif). Masing-masing perusahaan dikaji secara berdiri sendiri - teknik pengolahan multikasus.

Data yang digunakan adalah data primer, diperoleh melalui wawancara pada periode semester ganjil 2011-2012 dan genap 2011-2012. Ada beberapa data situasi perusahaan yang diperoleh dari pengamatan (observasi) langsung di lapangan dan melalui pengisian kuesioner singkat. Secara garis besar laporan dibagi menjadi dua bagian: 1) mengenai profil dan sejarah perusahaan; 2) mengenai gambaran masalah yang dihadapi, diarahkan pada tiga dimensi perkembangan.

Teknik pengumpulan data yang dipakai dalam penelitian ini adalah wawancara, dilengkapi dengan beberapa pertanyaan penuntun dan pengisian profil perusahaan. Wawancara dilakukan dengan dicatat dan direkam, untuk disusun menjadi transkrip. Observasi dilakukan untuk melihat situasi fisik perusahaan saat ini, melengkapi data dari wawancara.

Presentasi dan diskusi dilakukan diantara kelompok surveyor untuk menyamakan pandangan terhadap sasaran data yang dibutuhkan, sesuai dengan masalah penelitian. Kegiatan ini dilakukan berulangulang. Output laporan tertulis dari surveyor harus lengkap sesuai dengan standar yang ditentukan.

\section{HASIL}

Informasi dari 45 bisnis keluarga yang ada di Bandung dan sekitarnya, dikelompokkan berdasarkan waktu berdirinya, seperti yang digunakan dalam tulisan David dan Leny (2007) yaitu:

1. Bisnis didirikan sebelum tahun 1967 (sebanyak 7 perusahaan).

2. Bisnis didirikan antara tahun 1968-1979 (sebanyak 18 perusahaan).

3. Bisnis didirikan antara 1980 -1991 (sebanyak 11 perusahaan).

4. Bisnis didirikan setelah tahun 1992 (sebanyak 8 perusahaan).

\section{Profil Bisnis Keluarga di Bandung}

Bisnis keluarga di Bandung dapat berumur panjang misalnya: Toko Aroma, sudah berdiri sejak tahun 1930, Toko Sim berdiri di tahun 1962. Usia bisnis kelompok yang berdiri setelah tahun 1992, mereka dapat melewati usia kritis tiga tahun atau lima tahun pertama. Dapat diperkirakan bisnis keluarga di Bandung mempunyai kemampuan bertahan dan berlanjut. 
Tabel 4. Bisnis Didirikan Sebelum Tahun 1967

\begin{tabular}{lcll}
\hline \multicolumn{1}{c}{ Nama Perusahaan } & $\begin{array}{c}\text { Tahun } \\
\text { Berdiri }\end{array}$ & Jenis usaha & Generasi yang Aktif \\
\hline Toko Siem, Bandung & 1962 & Distributor/Ritel produk konsumen & Generasi 2 \\
Kopi Aroma, Bandung & 1930 & Pabrik kopi & Generasi 2 \\
PT Saung Angklung Ujo, Bandung & 1950 & Jasa kesenian daerah & Generasi 2 dan 3 \\
Mie Lezat, Bandung & 1960 & Kuliner & Generasi 2 dan 3 \\
PT Panca Putera (Kedaung Grup), Bandung & 1958 & Produk perabot rumah tangga & Generasi 2 \\
Lin Kie & 1920 & Nasi campur & Generasi 3 \\
\hline
\end{tabular}

Tabel 5. Bisnis Dirikan Antara Tahun 1968-1979

\begin{tabular}{lcll}
\hline \multicolumn{1}{c}{ Nama Perusahaan } & Tahun Berdiri & Jenis Usaha & Generasi yang Aktif \\
\hline PT Limas Raga Inti, Bandung & 1972 & Distributor LPG & Generasi 1 dan 2 \\
Tizi cake shop, Bandung & 1973 & Kuliner & Generasi 2 \\
Sadang Jaya, Bandung & 1972 & Pabrik tekstil - kain grey & Generasi 1 dan 2 \\
Kue Ny. Betty, Bandung & 1972 & Pabrik kue basah: bika dan pepe & Generasi 2 \\
PT Setia Jaya, Majalaya & 1977 & Pabrik tekstil & Generasi 1 dan 2 \\
Sate Sidaredja (Pak Gino), Bandung & 1978 & Kuliner & Generasi 1 \\
WG Grup, Bandung & 1974 & Automotif dan properti & Generasi 2 \\
\hline
\end{tabular}

Tabel 6. Bisnis Didirikan Antara Tahun 1980-1991

\begin{tabular}{lcll}
\hline \multicolumn{1}{c}{ Nama Perusahaan } & Tahun Berdiri & \multicolumn{1}{c}{ Jenis Usaha } & Generasi yang Aktif \\
\hline PD Sinar Karya, Bandung & 1987 & Dealer Honda & Generasi 1 dan 2 \\
Glosis Grill (Bandung, Jakarta) & 1984 & Kuliner & Generasi 1 dan 2 \\
CV Cahaya Harapan & 1980 & Garmen & Generasi 1 dan 2 \\
CV Enggal Biskuit & $1980-a n$ & Pabrik kue biskuit & Generasi 1 \\
Prima Rasa, Bandung & 1982 & Kue dan bolu & Generasi 1 dan 2 \\
CV Vicci, Bandung & 1989 & Pabrik tas & Generasi 1 \\
PT Catur Kartika Jaya, Cileunyi & 1985 & Pabrik tekstil & Generasi 1 \\
\hline
\end{tabular}

Tabel 7. Bisnis Didirikan Setelah Tahun 1992

\begin{tabular}{lcll}
\hline \multicolumn{1}{c}{ Nama Perusahaan } & Tahun Berdiri & Jenis Usaha & Generasi yang Aktif \\
\hline EcoMart, Bandung & 2004 & Ritel & Generasi 1 dan 2 \\
CV William Jaya Pratama, Bandung & 1995 & Garmen & Generasi 1 dan 2 \\
Jump'n Gym, Bandung & 2004 & Jasa penitipan anak & Generasi 1 \\
PT Digigames Indonesia Persada, Bandung & 2001 & Game Online & Generasi 1 \\
PT Kartika Sari Sejati & 2004 & Kue dan bolu & Generasi 1 \\
\hline
\end{tabular}


Beberapa bisnis keluarga sedang dijalankandikendalikan oleh generasi kedua atau generasi ketiga. Walaupun cukup banyak bisnis keluarga pada kelompok usia 20-40 tahun belum melakukan alih generasi. Sementara pada beberapa bisnis keluarga yang didirikan pada abad 20 menunjukkan perkembangan menarik, yaitu generasi kedua sudah langsung dilibatkan ketika membangun usaha baru tersebut. Masalah alih generasi pada bisnis keluarga ini tampaknya tidak terlalu baik dipersiapkan atau tidak dikelola sama sekali, tetapi alih generasi tetap berlangsung.

Bisnis keluarga, yang berskala mikro-kecil (bisnis kuliner), tampaknya dapat tetap bertahan sampai turun temurun (sejak tahun 1920), dengan melakukan pemecahan bisnis (regenerasi) diantara penerus, yang diberi masing-masing hak untuk membuat sebuah rumah makan dengan menggunakan resep leluhur (rahasia), misal: Rumah Makan Lin Kie dan Mie Lezat.

Bisnis keluarga di Bandung, yang merupakan bisnis kecil-menengah, dapat bertumbuh dan menambah divisi, sehingga dapat menjadi bisnis skala besar, misalnya: PT Renaldi Eka Inti, PD Borma, PT Panca Putera (Kedaung Grup). Bisnis keluarga (UKM) tampaknya berpeluang menjadi ukuran usaha besar, selain adanya kesiapan manajemen, juga adanya faktor kesempatan dari eksternal. Industri ritel dan outlet merupakan salah satu yang berkembang di Bandung, tetapi untuk industri tekstil dan garmen sedang menurun.

\section{Potret Tiga Dimensi Perkembangan Bisnis Keluarga}

\section{Sandang Jaya}

Didirikan pada tahun 1972, bidang usaha tekstil.

a. Dimensi Bisnis

Berada di tahap dewasa, ditandai dengan sudah tidak ada perkembangan bisnis yang berarti baik dari sisi pasar atau produk maupun organisasi. Perusahaan sudah mantap dijalankan dengan manajemen yang sudah dianggap memadai.

b. Dimensi Keluarga

Kekuasaan sudah dilepaskan pada penerusnya. Dengan usia direktur atau pemilik saat ini sudah berusia 81 tahun, sudah menyerahkan pengendalian perusahaan pada 3 anaknya sejak lama. Masing-masing anak mendapat kekuasaan dan wewenang yang jelas. Generasi kedua merasa khawatir sudah tidak bisa untuk menjalankan sebuah bisnis bersama-sama - khawatir terjadi konflik karena sudah pada tingkat sepupu (dari
3 orang tua bersaudara). Generasi ketiga sudah berada pada usia dapat memasuki bisnis.

Alternatif manajemen diserahkan pada profesional, dengan beberapa kepemilikan keluarga dijual kepada salah satu keluarga yang memiliki komitmen.

c. Dimensi Pemilik

Kepemilikan masih pada pengendalian keluarga. Kekuasaan generasi pertama sudah mulai terbatas. Generasi kedua yaitu saudara kandung bersama-sama memiliki dan dapat mengendalikan perusahaan dengan ketentuan yang ada.

Untuk menjadi stabilitas-harmonis keluarga. Mungkin kepemilikan dapat dipertahankan pada generasi kedua, sementara generasi ketiga masuk ke manajemen, dengan membuat organisasi dan peraturan yang lebih jelas.

\section{PD Sinar Karya}

Didirikan tahun 1987, Dealer Honda.

a. Dimensi Bisnis

Perusahaan ini sedang berada di tahap Ekspansi, berkembang cepat. Sesuai dengan keadaan lingkungan usaha dalam industri motor yang memberikan kesempatan untuk berkembang baik. Ditambah dukungan sikap profesional dan kompetensi pendiri-pemiliknya.

Tuntutan untuk mengembangan organisasi dan sistem sejalan dengan pertumbuhan bisnis dan pasar dari indutri ini, kelihatannya mau tidak mau harus berubah. Posisi yang menguntungkan karena berhubungan dengan Perusahaan nasional (Astra: Merk Honda). Sistem dan dukungan sumber daya harus terus dikembangkan untuk memenuhi standar sebagai dealer.

b. Dimensi Keluarga

Mulai bergabung kedua anaknya ke dalam bisnis. Keluarga ini memiliki empat anak: 3 laki laki dan 1 perempuan; 2 anak yang sudah dewasa yang sudah mulai membantu, 2 anak yang lain masih usia sekolah.

Persiapan suksesi sudah ada, sikap orang tua yang memberikan kesempatan untuk belajar dan memilih karir. Pendampingan dilakukan oleh orang tua (suami istri) ketika anak bergabung dalam perusahaan.

c. Dimensi Pemilik

Kepemilikan dan pengendalian masih sepenuhnya pada generasi pertama, pendirinya (suami istri). 
Pendiri (suami), khususnya memimpin di Laswi, dibantu oleh seorang anaknya. Sedangkan istrinya, khususnya memimpin di Ahmad Yani, dibantu juga oleh seorang anak yang lain. Anak memasuki bisnis, mulai dari kedudukan yang bawah atau pelaksana. Adanya pembagian posisi dan imbalan-gaji untuk anak-anak yang sudah ikut membatu.

\section{Anarasa}

Didirikan tahun 1990, Pabrik Biskuit.

a. Dimensi Bisnis

Berada pada tahap perkembangan. Sebagai bisnis yang masih baru yang bergerak dalam industri makanan, berpotensi tumbuh. Pesaing tidak terlalu banyak yang harus dihadapi karena di kota kecil Sumedang. Organisasi sederhana tetapi sudah jelas pembagiannya. Dibutuhkan sistem akuntansi untuk laporan dan keterbukaan antar pemilik saudara kandung. Untuk menjaga rasa saling percaya.

b. Dimensi Keluarga

Berada pada posisi pembisnis muda, generasi pertama (empat bersaudara) mempunyai semangat untuk bersama menjalankan bisnisnya. Peran kepemimpinan keluarga kakak terbesar sangat menentukan jalannya usaha keluarga ini. Walaupun ada keinginan anggota keluarga untuk mempunyai usaha sendiri-sendiri, usaha ini dipertahankan.

c. Dimensi Pemilik

Berada pada tahap pertama, yaitu pengendalian pemilik dan manajemen oleh empat saudara kandung. Peraturan tentang bagi hasil dan ketentuan atau peraturan yang terkait dengan penggunaan kekayaan perusahaan seharusnya dibuat, tidak cukup hanya ada figur pemimpin yang kuat yang dapat menjaga hubungan keluarga bisa harmonis.

Melihat potret Tiga Dimensi Perkembangan Bisnis Keluarga: PT Sandang Jaya, PD Sinar Karya, dan Anarasa, yang memiliki tahap siklus yang unik. Masing-masing perusahaan memiliki posisi siklus yang berbeda.

PD Sinar Karya dan Anarasa dimensi Bisnisnya sama-sama berada pada tahap berkembang. Namun Sinar Karya dimiliki oleh suami-istri , sedangkan Anarasa dimiliki oleh 4 bersaudara adik-kakak, hal ini menunjukkan ke dua perusahaan itu berada pada posisi-siklus dan kompleksitas yang berbeda. Lain halnya dengan Sandang Jaya tahap bisnisnya berada pada tahap dewasa, pada saat ini perusahaan tidak melakukan pengembangan usaha yang berarti. Ke tiga perusahaan tsb berada pada siklus mereka yang unik artinya masing-masing menghadapi tantangan utama yang berbeda. Perusahaan yang tahapnya sedang berkembang ataupun yang tahapnya sudah dewasa, akan menerapkan strategi dan cara bisnis yang berbeda, sesuai dengan situasi mereka.

\section{PEMBAHASAN}

\section{Mendirikan Bisnis Bersama Keluarga}

Anggota keluarga yang menduduki posisi pemilik dan manajer, lebih didominasi laki-laki (ayah, suami, anak laki-laki dan seterusnya). Ketika usaha mulai didirikan, lebih banyak yang melakukannya sendirian daripada bersama (keluarga atau bukan keluarga). Bila memulai bisnis bersama keluarga, kelihatannya lebih banyak bersama pasangan atau saudara kandung daripada dengan saudara jauh.

Hampir semua pendiri-pemilik menjadi direktur utama atau manajer operasi-pemasaran. Bila pemilik melibatkan istrinya dalam bisnis, posisi istri dalam manajemen umumnya sebagai pengelola keuangan.

Berbisnis bersama saudara kandung, kelihatannya lebih sedikit dari bisnis yang dilakukan bersama pasangan. Tidak cukup banyak bisnis keluarga yang dijalankan oleh lebih dari sebuah keluarga (pasangan suami istri). Ada dua buah kasus bisnis keluarga yang dimiliki dan dijalankan oleh tiga dan empat pasangan suami istri (bersaudara). Akibatnya ada kerumitan bisnis yang lebih tinggi.

Dalam bisnis keluarga yang dimiliki suku Sunda (Saung Angklung Ujo, Resto Glosis), tampak lebih banyak mengikutkan keluarga yang lebih luas (semenda), dan melibatkannya baik dalam posisi manajemen maupun pekerja. Kedudukan secara formal dalam bisnis tidak membatasi peran keluarga yang tidak terlibat langsung untuk memberikan dukungannya.

Dalam menjaga stabilitas bisnis keluarga, selalu ada peran pemimpin baik yang terlibat langsung maupun yang tidak terlibat langsung dalam bisnis. Figur kepemimpinan dari orang tua atau orang yang "dituakan" sangat berarti dalam menjaga stabilitas dan harmoni dalam hubungan keluarga, terutama ketika sistem dan ketentuan atau aturan formal yang dimiliki bisnis keluarga masih bersifat terbatas. 
Membuka diri terhadap kehadiran bukan keluarga dalam kepemilikan dan manajemen. Dari 45 kasus, hanya ada satu kasus bisnis yang dijalankan dengan kepemilikan bersama teman, sisanya bersama keluarga. Sedangkan untuk melibatkan bukan keluarga menjadi manajer, ada tiga perusahaan saja yang sudah melakukan, untuk jabatan di level supervisor. Bisnis yang didirikan dalam 5-10 tahun terakhir mempunyai pandangan yang lebih terbuka terhadap kehadiran peran bukan keluarga untuk menduduki fungsi manajemen. Anggota keluarga yang tidak kompeten dan sesuai untuk manajemen seharusnya tidak dipaksakan untuk terlibat.

\section{Kebutuhan Formalitas dan Profesionalitas}

Pada Dimensi Perkembangan Bisnis, ketika usaha berhasil melewati tahap "kewirausahaan"nya, cepat atau lambat pendirinya akan merasa memerlukan administrasi sederhana untuk mendukung perkembangan bisnis selanjutnya. Kebutuhan administrasi meningkat sejalan bisnis menjadi lebih besar, orang yang terlibat dalam pekerjaan semakin banyak, dan keterlibatan keluarga meluas.

Adanya pencatatan aktivitas, pembukuan dan pengaturan pekerjaan, pembagian tugas dan tanggung jawab yang memadai akan mendukung perkembangan bisnis lebih lanjut. Proses formalisasi yang berjalan baik selain memperlancar kegiatan usaha sekaligus membangun dasar profesionalitas dalam bisnis keluarga.

Pengaturan untuk membagi tanggung-jawab atau tugas dan sistem imbalan yang adil sangat penting dalam bisnis keluarga. Peraturan dan sistem kepegawaian dapat menciptakan suasana kerja profesional baik di antara anggota keluarga maupun pekerja yang non-keluarga. Formalitas dan profesional yang akan dibangun seyogyanya tetap fleksibel, karena anggota keluarga biasanya memiliki komitmen dan kebajikan pribadi yang lebih tinggi yang dapat dimanfaatkan menjadi nilai lebih pada bisnis keluarga.

\section{KESIMPULAN}

Beberapa bisnis keluarga di Bandung, dianalisis dengan Model Perkembangan Tiga Dimensi. Setiap kasus bisnis keluarga berada pada perkembangan bisnis, perkembangan keluarga dan perkembangan kepemilikan yang berbeda.
Temuan umum, tentang Keberlanjutan dan Perkembangan Bisnis Keluarga (UKM) di Bandung adalah:

1. Terdapat keberlanjutan bisnis keluarga dengan bisnis-bisnis telah berusia panjang, perkembangan skala bisnis dan regenerasi bisnis pada penerusnya.

2. Keberlanjutan itu mungkin didukung oleh, antara lain: peran keluarga dalam manajemen dan kepemilikan: terdapat komitmen dan kepercayaan pada keluarga yang tinggi; posisi bisnis yang sudah dewasa: posisi persaingan di pasar sudah mantap dan kapasitas usaha dan modal yang kuat; dan stabilitas pengelolaan bisnis yang mengandalkan kepemimpinan dari figur yang berasal dari keluarga

Ditemukan juga keadaan manajemen dan sistem yang tidak cukup berkembang, di mana ketidakterbukaan terhadap bukan keluarga profesional akan dapat menyebabkan bisnis keluarga di Bandung tidak inovatif dan berkembang (menurun sejalan persaingan yang semakin ketat).

Untuk keberlanjutan bisnis di masa depan: perlu perubahan paradigma pelaku bisnis keluarga tentang manajemen, organisasi-sistem dan profesionalitas.

Kelemahan penelitian ini, setiap kasus dikaji dalam Model Perkembangan Tiga Dimensi dimana tidak dilakukan bersama pelaku bisnis atau agen yang terlibat dalam bisnis yang dimaksud, sehingga terdapat kemungkinan posisi perkembangan yang telah ditetapkan akan berubah.

\section{DAFTAR PUSTAKA}

A.B. Susanto, H. W. 2007. Family Business. The Jakarta Consulting Group.

Academy (IFERA). Family Business Review, 235.

Anonymous. 2003. Family Businesses Dominate: International Family Enterprise Research

Gersick, K. E., Davis, J. A., McCollom, M., \& Lansberg, I. 1997. Generation to Generation. Massachusetts: Harvard Business School Press.

Greiner, L. E. 1972. Evolution and Revolution as Organizations Grow: A Company's past has clues for management that are critical to future success. Harvard Business Review , 397.

Lester, D. L., \& Parnell, J. A. The Complete Life Cycle of A family Business. Arkansas. 
Lissoni, J., Pereira, M. F., Serra, F., \& Ribeiro de Almeida, M. 1999. Family Business Lifecycle; The Application of 7Ss Framework.

Poza, E. 2010. Family Business. Canada: South Western Cengage Learning.
Sharma, P. 2004. An Overview of the Field of Family Business Studies: Current Status and Directions for the Future. Family Business Review, 1.

Zachary, R. K. 2011. The importance of the family system in family business. Journal of Family Business Management, 26-36. 